\title{
Effect of eosinophil cationic protein on human oral squamous carcinoma cell viability
}

\author{
PRISCILA OLIVEIRA DE LIMA ${ }^{1}$, FÁBIO VIEIRA DOS SANTOS ${ }^{1}$, DENISE TOSTES OLIVEIRA ${ }^{2}$, \\ ROBERTA CARVALHO DE FIGUEIREDO ${ }^{1}$ and MICHELE CONCEIÇÃO PEREIRA ${ }^{1}$ \\ ${ }^{1}$ Federal University of São João Del Rei-Midwest Campus Dona Lindu, Divinópolis, MG 35501-296; \\ ${ }^{2}$ Bauru School of Dentistry, University of São Paulo, Bauru, SP 17012-901, Brazil
}

Received September 12, 2014; Accepted October 22, 2014

DOI: $10.3892 / \mathrm{mco} .2014 .477$

\begin{abstract}
The exact function of eosinophils in cancer, particularly in oral squamous cell carcinoma (OSCC), has not yet been elucidated and the possible antitumor effect of these leukocytes is associated with the release of cytotoxic proteins, particularly eosinophil cationic protein (ECP). The aim of this study was to evaluate the effect of ECP on human OSCC lines and to provide novel insights into the role of eosinophils in these tumors. The viability of the SCC- 4 and SCC- 25 OSCC cell lines was assessed by colorimetric assay using 3-(4,5-dimethylthiazol-2-yl)-2,5-diphenyltetrazolium bromide (MTT). The cells were plated into 96-well plates in Dulbecco's modified Eagle's medium/Ham's nutrient mixture F12 supplemented with $10 \%$ fetal bovine serum. After $24 \mathrm{~h}$, the indicated concentration of ECP $(0-10 \mu \mathrm{M})$ was added to each sample. The plate was read using a microplate reader at a wavelength of $570 \mathrm{~nm}$. The association between variables was estimated by linear regression analysis. There was a significant inverse association between ECP concentrations with SCC-4 ( $\beta=0.16$, $\mathrm{P}=0.019)$ and $\mathrm{SCC}-25$ cell viability $(\beta=0.24, \mathrm{P}=0.006)$. To the best of our knowledge, the present study was the first to investigate the effects of ECP on OSCCs and to demonstrate a significant inverse association between ECP concentrations with SCC-4 and SCC-25 cell viability.
\end{abstract}

\section{Introduction}

Eosinophil cationic protein (ECP), found in the secondary granules of human eosinophils, is a single-chain peptide of 133 amino acids, with a molecular mass ranging between 15 and $22 \mathrm{kDa}$, encoded by the RNSE3 gene located

Correspondence to: Professor Michele Conceição Pereira, Federal University of São João Del Rei-Midwest Campus Dona Lindu, 400 Sebastião Gonçalves Coelho Avenue, Chanadour, Divinópolis, MG 35501-296, Brazil

E-mail: michelepereira@ufsj.edu.br

Key words: eosinophil cationic protein, cytotoxic activity, oral squamous cell carcinoma, eosinophils on chromosome 14q11.2. Its amino acid sequence and three-dimensional structure indicate that ECP is a member of the ribonuclease A superfamily (1-7). Protein heterogeneity is a result of post-translational modifications, such as differences in glycosylation of the molecule, since there are three potential sites for N-linked glycosylation in the ECP amino acid sequence $(6,8-12)$.

ECP has a number of biological activities, including suppression of T-cell proliferative responses and immunoglobulin synthesis by B cells, mast cell degranulation, regulation of fibroblast activities, induction of airway mucus secretion and interaction with the coagulation and complement systems $(5,10,13)$. Furthermore, the most striking function of ECP is its cytotoxic activity against bacteria, parasites, viruses, respiratory epithelial and cancer cells $(2,4,8,9,12,13)$. The mechanism of action of ECP is mediated through its cytotoxic capacity to create pores in the cell membrane, with ensuing destabilization of the phospholipid bilayer and osmotic cell lysis $(2,9,11,14,15)$.

According to Navarro et al (4), the effect of ECP begins with its binding and aggregation on the cell surface, which alters the cell membrane permeability and modifies the cell ionic equilibrium. These signals induce cell-specific morphological and biochemical changes, such as chromatin condensation, reversion of membrane asymmetry, production of reactive oxygen species, activation of caspase-3-like activity and, eventually, cell death. In addition, the high number of arginine residues on the surface of the protein (16) and the tryptophan residues at positions 10 and $35(2,16)$ appear to be crucial for the cytotoxic activity of ECP.

The exact function of eosinophils in cancer, particularly in oral squamous cell carcinoma (OSCC), has not yet been fully elucidated (17-21). Certain authors support the hypothesis that eosinophils play a significant role in the host defense against cancer, whereas others suggest that the antitumor effect of eosinophils in human is modest at best, particularly in view of the numerous examples of aggressive cancers that continue to proliferate and spread, although they are infiltrated by significant numbers of eosinophils (20).

The antitumor effect of eosinophils $(5,6,19,21,22)$ has been associated with the release of cytotoxic proteins, including ECP. Furthermore, the blood eosinophil counts and serum concentration of ECP were found to be significantly higher when 
compared between prior to and during treatment with interleukin-2 (IL-2) and interferon (IFN)- $\alpha$ in patients with renal cell adenocarcinoma (22). Based on those results, the authors hypothesized that, although the precise mechanisms involved in the induction of the release of the eosinophil-derived products are not known, potential candidates are tumor necrosis factor (TNF)- $\alpha$ and the direct interaction of the eosinophils with cancer cells through antibody-dependent mechanisms.

The aim of the present study was to investigate the effect of ECP on human OSCC lines and provide novel insights into the role of eosinophils in these tumors.

\section{Materials and methods}

Cell culture. The SCC-4 and SCC-25 cell lines (American Type Culture Collection, Manassas, VA, USA) were maintained in Dulbecco's modified Eagle's medium/Ham's nutrient mixture F12 (DMEM/F12; Invitrogen, Carlsbad, CA) supplemented with $10 \%$ fetal bovine serum (Invitrogen), $400 \mathrm{ng} / \mathrm{ml}$ hydrocortisone and $100 \mu \mathrm{g} / \mathrm{ml}$ gentamycin and kanamycin at $37^{\circ} \mathrm{C}$ in a humidified atmosphere of $5 \% \mathrm{CO}_{2}$, as described by Agostini et al (23).

Evaluation of cellular morphology. The effects of the ECP on cell morphology were observed using an inverted light microscope (Eclipse E200; Nikon, Tokyo, Japan) and were photographed prior to and after treatment, to document possible changes in morphology.

Cell viability assay. The effect of ECP on SCC-4 and SCC-25 cell viability was assessed by colorimetric assay using 3-(4,5-dimethylthiazol-2-yl)-2,5-diphenyltetrazolium bromide (MTT), as described by Gomes et al (24).

Briefly, SCC-4 and SCC-25 cells were cultured in 96-well plates for $24 \mathrm{~h}$ in DMEM/F12 supplemented with $10 \%$ fetal bovine serum at $2 \times 10^{5}$ cells per well. The ECP (MyBioSource, LLC, San Diego, CA, USA) was diluted in complete medium to prepare samples of different concentrations. Negative control wells received $100 \mu \mathrm{l}$ of complete medium, whereas the treated cells were incubated for $72 \mathrm{~h}$ with 0.0390625 , $0.078125,0.15625,0.3125,0.625,1.25,2.5,5$ and $10 \mu \mathrm{M}$ of ECP (final volume, $100 \mu \mathrm{l} /$ well). At the end of the incubation, the medium was removed and each well received $50 \mu 1$ of MTT solution $(0.5 \mathrm{mg} / \mathrm{ml}$ in PBS buffer; Sigma-Aldrich Corp., St. Louis, MO, USA), including 6 wells without cells (blanks). The plates were incubated at $37^{\circ} \mathrm{C}$ for $4 \mathrm{~h}$ followed by the addition of $200 \mu \mathrm{l}$ of dimethylsulfoxide to each well and incubation with shaking at $37^{\circ} \mathrm{C}$ for $20 \mathrm{~min}$ to ensure complete dissolution of the formazan crystals. The resulting absorbances were read at $570 \mathrm{~nm}$ in a microplate reader (PowerWave XS2; Biotek Instruments, Inc. Winooski, VT, USA) and cell viability was calculated using the following equation:

$$
\text { Cell viability }(\%)=\frac{A-B}{C-D} \times 100
$$

where $\mathrm{A}$ is the absorbance of the treated cells, $\mathrm{B}$ is the absorbance of the blank and $\mathrm{C}$ is the absorbance of the control. All the experiments were performed in triplicate. The viability mean was used in the statistical analysis.
Statistical analysis. Data are expressed as mean \pm standard deviation and stored in Microsoft Excel for Windows for later analysis with Stata software, version 11.0 (StataCorp LP, College Station, TX, USA). The association between ECP concentration (independent variable) and cell viability (dependent variable) was estimated by linear regression analysis. Two analyses were performed, for SCC-4 and SCC- 25 cells. As cell viability is not normally distributed, prior to statistical analysis, the values were logarithmically transformed to approximate a normal distribution. The ECP concentration was entered in the analysis as a continuous variable. P-values $<0.05$ were considered to indicate statistically significant differences.

\section{Results}

Morphological changes. Direct observation under a light microscope was used to assess the morphological changes of SCC-4 and SCC-25 cell cultures following exposure to ECP. The cells treated with ECP were photographed at $72 \mathrm{~h}$ following treatment and morphological changes, such as vacuolation, bleb formation and loss of cell adhesion were identified (Fig. 1).

Cell viability. There was a significant inverse association between ECP concentrations with SCC-4 $(\beta=0.16, \mathrm{P}=0.019)$ and SCC-25 $(\beta=0.24, \mathrm{P}=0.006)$ cell viability (Table I). The regression analysis demonstrated that the ECP concentration explained $\sim 52 \%$ of the variations in SCC-4 viability and $\sim 64 \%$ of those in SCC-25 viability.

\section{Discussion}

The mechanisms that cause eosinophil recruitment to malignant neoplasms have not been fully elucidated $(18,20,25)$. A complex mixture of the components of innate and adaptive immune responses are likely to be involved in this process $(21,26)$. Currently available evidence suggests that $\mathrm{CD}^{+} \mathrm{T}$ lymphocytes and natural killer cells are capable of producing the Th2-mediated cytokines IL-4 and IL-5, thus providing strong eosinophil-specific chemoattractants and activation signals within the tumor environment $(21,26)$.

Additionally, the eosinophils are considered to be recruited to tumors, in part, by the selective eosinophil chemoattractant eotaxin, which binds to the CCR3 receptor on these cells $(21,25-27)$. The expression of eotaxin in OSCC was investigated by Lorena et al (25), whose results demonstrated that eotaxin is mainly produced by tumor-associated eosinophils, which appears to increase the cell turnover rate in oral cancer.

It was previously suggested that eosinophils may affect tumors via direct and/or indirect mechanisms and it appears that the tumor microenvironment may provide additional signs for eosinophil degranulation and tumor destruction $(19,21)$. The antitumor effect of eosinophils $(5,6,21,22)$ has been associated with the release of cytotoxic proteins, including ECP, which has been linked to tumor cell apoptosis.

Furthermore, blood eosinophil counts and the serum concentration of ECP were found to be significantly higher prior to and during treatment with IL-2 and IFN- $\alpha$ in patients with renal cell adenocarcinoma (22). Based on those results, the 
Table I. Regression coefficients (95\% CI) for the association of ECP concentration with SCC-4 and SCC-25 cell viability.

\begin{tabular}{lccc}
\hline Cell lines & $\beta(95 \% \mathrm{CI})^{\mathrm{a}}$ & $\mathrm{P}$-value & $\mathrm{R}^{2}$ \\
\hline SCC-4 & $0.16(0.03-0.27)$ & 0.019 & 51.9 \\
SCC-25 & $0.24(0.09-0.38)$ & 0.006 & 63.9 \\
\hline
\end{tabular}

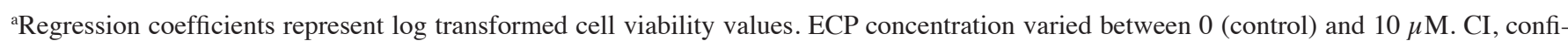
dence interval; ECP, eosinophil cationic protein.
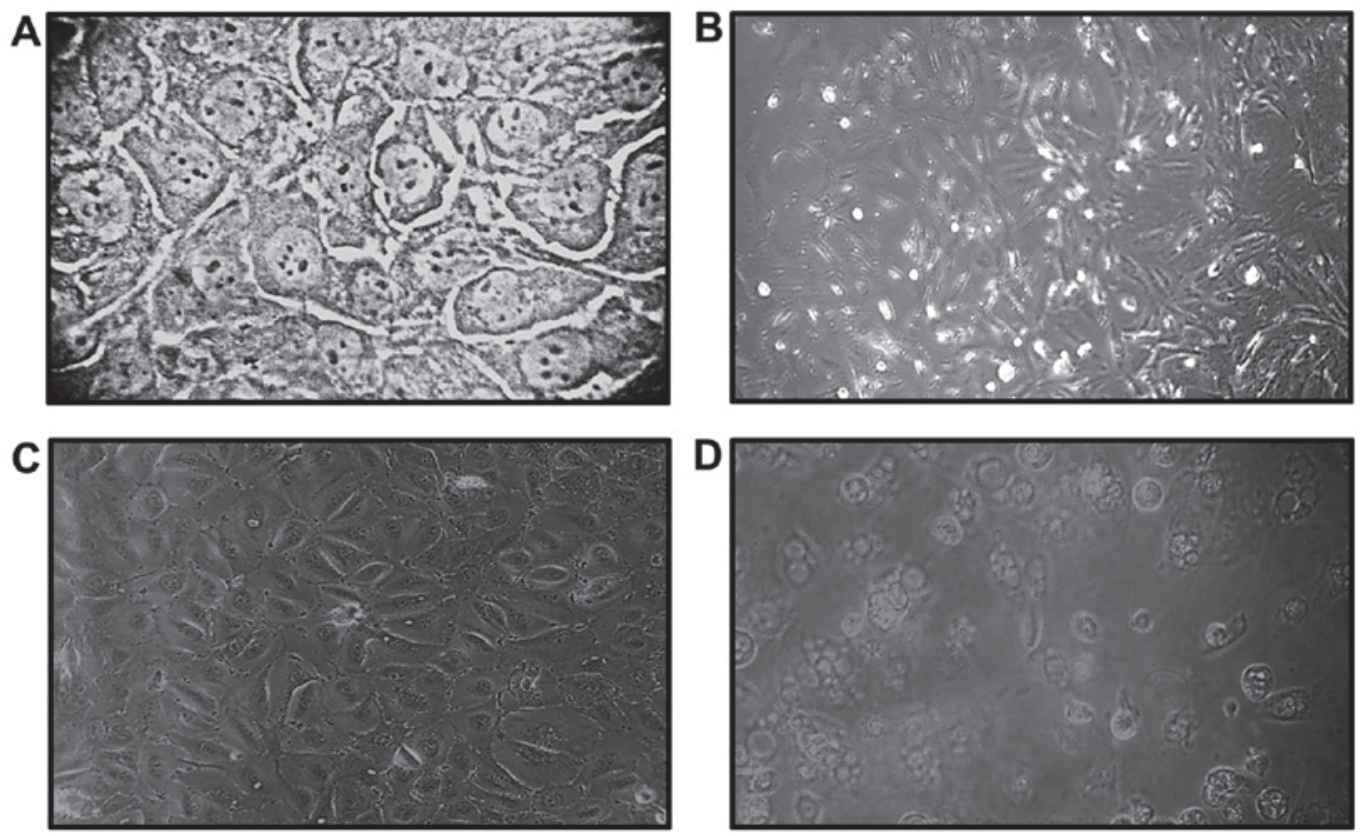

Figure 1. Morphological characteristics of the cell lines observed under an inverted light microscope. SCC-4 cells (A) prior to treatment with ECP and (B) after $72 \mathrm{~h}$ of exposure to ECP. SCC-25 cells (C) prior to treatment with ECP and (D) after $72 \mathrm{~h}$ of exposure to ECP.

authors hypothesized that, although the precise mechanisms involved in the induction of the release of eosinophil-derived products are not known, potential candidates are TNF- $\alpha$ and the direct interaction of the eosinophils with cancer cells through antibody-dependent mechanisms.

Our results demonstrated that OSCC lines treated with ECP displayed morphological changes, such as vacuolation, bleb formation and loss of adhesion (Fig. 1). As we were investigating cell death, a longer period of $72 \mathrm{~h}$ was selected. Similar findings were described by Trocmé et al (28), who exposed primary human corneal epithelial cell cultures to $\mathrm{ECP}$ at concentrations ranging between 0 and $10 \mu \mathrm{g} / \mu \mathrm{l}$ for up to $48 \mathrm{~h}$. According to that study, the morphological changes in the cells observed following ECP exposure may be partially explained by its effects on the epithelial actin cytoskeleton. Indeed, the actin filaments have been implicated in the control of cell shape and cell adhesion to the substratum.

In our study, the regression analysis demonstrated that an increase in the ECP concentration was associated with a significant decrease in SCC-4 and SCC-25 cell viability (Table I). Maeda et al (29) evaluated the effect of ECP on 13 mammalian cell lines and reported that this protein inhibited the growth of several cell lines, including those derived from skin and esophageal squamous carcinoma, in a dose-dependent manner.
Glimelius et al (30) investigated the effects of ECP on Hodgkin's lymphoma cells in vitro. Of note, ECP was cytotoxic even at low concentrations; however, ECP was unable to eliminate all tumor cells, particularly not HDLM-2 cells (of T-cell origin), even at high concentrations and a prolonged exposure time $(72 \mathrm{~h})$. Based on those results, the authors suggested that one possible mechanism of such selectivity may be the different sensitivities according to the cell cycle stage of the cell population. HDLM-2 cells in the G0 phase may be insensitive to ECP and only cells in active growth phases are eliminated by ECP.

The mechanism of action of ECP is likely due to its cytotoxic capacity to create pores in the cell membrane, which allows the passage of water and other small molecules, leading to osmotic lysis of the target cell (15). The effects of ECP begin with its binding and aggregation on the cell surface, altering the cell membrane permeability and modifying the cell ionic equilibrium. These signals induce cell-specific morphological and biochemical changes, such as chromatin condensation, reversion of membrane asymmetry, reactive oxygen species production, activation of caspase-3-like activity and, eventually, cell death (4).

A cell line is not necessarily a good example of primary tumor material, as the cells are removed from the normal 
tissue environment, which may affect their response to ECP; however, it is important to emphasize that the present study was the first to investigate the effects of ECP on OSCC and to demonstrate a significant inverse association of ECP concentrations with SCC-4 and SCC-25 cell viability.

\section{Acknowledgements}

This study was supported by a research grant (no. APQ-00558-09) from the Foundation for Research Support of the State of Minas Gerais (FAPEMIG).

\section{References}

1. Byström J, Garcia RC, Håkansson L, et al: Eosinophil cationic protein is stored in, but not produced by, peripheral blood neutrophils. Clin Exp Allergy 32: 1082-1091, 2002.

2. Carreras E, Boix E, Navarro S, Rosenberg HF, Cuchillo CM and Nogues MV: Surface-exposed amino acids of eosinophil cationic protein play a critical role in the inhibition of mammalian cell proliferation. Mol Cell Biochem 272: 1-7, 2005.

3. Molin D: Bystander cells and prognosis in Hodgkin lymphoma. Review based on a doctoral thesis. Ups J Med Sci 109: 179-228, 2004.

4. Navarro S, Aleu J, Jiménez M, Boix E, Cuchillo CM and Nogués MV: The cytotoxicity of eosinophil cationic protein/ribonuclease 3 on eukaryotic cell lines takes place through its aggregation on the cell membrane. Cell Mol Life Sci 65: 324-337, 2008.

5. Venge $\mathrm{P}$ and Byström J: Eosinophil cationic protein (ECP). Int J Biochem Cell Biol 30: 433-437, 1998.

6. Venge P, Byström J, Carlson M, et al: Eosinophil cationic protein (ECP): molecular and biological properties and the use of ECP as a marker of eosinophil activation in disease. Clin Exp Allergy 29: 1172-1186, 1999.

7. Zhang J and Rosenberg HF: Sequence variation at two eosinophil-associated ribonuclease loci in humans. Genetics 156: 1949-1958, 2000.

8. Eriksson J, Woschnagg C, Fernvik E and Venge P: A SELDI-TOF MS study of the genetic and post-translational molecular heterogeneity of eosinophil cationic protein. J Leukoc Biol 82: 1491-1500, 2007.

9. Eriksson J, Reimert CM, Kabatereine NB, et al: The $434(\mathrm{G}>\mathrm{C})$ polymorphism within the coding sequence of eosinophil cationic protein (ECP) correlates with the natural course of Schistosoma mansoni infection. Int J Parasitol 37: 1359-1366, 2007.

10. Jönsson UB, Byström J, Stålenheim $G$ and Venge $P$ Polymorphism of the eosinophil cationic protein-gene is related to the expression of allergic symptoms. Clin Exp Allergy 32: 1092-1095, 2002.

11. Koh GCH, Shek LPC, Goh DYT, Van Bever H and Koh DSQ: Eosinophil cationic protein: Is it useful in asthma? A systematic review. Respira Med 101: 696-705, 2007.

12. Trulson A, Byström J, Engstrom A, Larsson R and Venge P: The functional heterogeneity of eosinophil cationic protein is determined by a gene polymorphism and post-translational modifications. Clin Exp Allergy 37: 208-218, 2007.
13. Byström J, Tenno T, Håkansson L, et al: Monocytes, but not macrophages, produce the eosinophil cationic protein. APMIS 109: 507-516, 2001

14. Sugihara R, Kumamoto T, Ito T, Ueyama H, Toyoshima I and Tsuda T: Human muscle protein degradation in vitro by eosinophil cationic protein (ECP). Muscle Nerve 24: 1627-1634, 2001.

15. Young JD, Peterson CGB, Venge P and Cohn ZA: Mechanism of membrane damage mediated by human eosinophil cationic protein. Nature 321: 613-616, 1986.

16. Carreras E, Boix E, Rosenberg HF, Cuchillo CM and Nogués MV: Both aromatic and cationic residues contribute to the membrane-lytic and bactericidal activity of eosinophil cationic protein. Biochemistry 42: 6636-6644, 2003.

17. Cormier SA, Taranova AG, Bedient C, et al: Pivotal advance: Eosinophil infiltration of solid tumors is an early and persistent inflammatory host response. J Leukoc Biol 79: 1131-1139, 2006.

18. Mingomataj EC: Eosinophil-induced prognosis improvement of solid tumors could be enabled by their vesicle-mediated barrier permeability induction. Med Hypotheses 70: 582-584, 2008.

19. Munitz A and Levi-Schaffer F: Eosinophils: 'new' roles for 'old' cells. Allergy 59: 268-275, 2004.

20. Samoszuk M: Eosinophils and human cancer: Histol Histopathol 12: 807-812, 1997.

21. Simson L, Ellyard JI, Dent LA, et al: Regulation of carcinogenesis by IL-5 and CCL11: a potential role for eosinophils in tumor immune surveillance. J Immunol 178: 4222-4229, 2007.

22. Trulson A, Nilsson S and Venge P: The eosinophil granule proteins in serum, but not the oxidative metabolism of the blood eosinophils, are increased in cancer. Br J Haematol 98: 312-314, 1997.

23. Agostini M, Silva SD, Zecchina KG, et al: Fatty acid synthase is required for the proliferation of human oral squamous carcinoma cells. Oral Oncol 40: 728-735, 2004

24. Gomes CC, Moreira LM, Santos VJSV, et al: Assessment of the genetic risks of a metallic alloy used in medical implants. Genet Mol Biol 34: 116-121, 2011.

25. Lorena SC, Oliveira DT, Dorta RG, Landman G and Kowalski LP: Eotaxin expression in oral squamous cell carcinomas with and without tumour associated tissue eosinophilia. Oral Dis 9: 279-283, 2003.

26. Ellyard JI, Simson L and Parish CR: Th2-mediated anti-tumour immunity: friend or foe? Tissue Antigens 70: 1-11, 2007.

27. Murdoch C, Muthana M, Coffelt SB and Lewis CE: The role of myeloid cells in the promotion of tumour angiogenesis. Nat Rev Cancer 8: 618-631, 2008.

28. Trocmé SD, Hallberg CK, Gill KS, Gleich GJ, Tyring SK and Brysk MM: Effects of eosinophil granule proteins on human corneal epithelial cell viability and morphology. Invest Ophthalmol Vis Sci 38: 593-599, 1997.

29. Maeda T, Kitazoe M, Tada H, et al: Growth inhibition of mammalian cells by eosinophil cationic protein. Eur J Biochem 269: 307-316, 2002.

30. Glimelius I, Rubin J, Fischer M, et al: Effect of eosinophil cationic protein (ECP) on Hodgkin lymphoma cell lines. Exp Hematol 39: 850-858, 2011. 